\title{
Vicarious Learning of FATA Women Entrepreneurs in Pakistan
}

\author{
Maryam Hina ${ }^{1}$, Zunaira Saqib ${ }^{2}$, Maria Khan ${ }^{3}$
}

\begin{abstract}
This study explores how women in Federally Administered Tribal Areas (FATA) learn and develop business skills through role models' assistance. The research is conducted with an interpretivist philosophy using qualitative methodology. The research concludes that FATA women's entrepreneurial self-efficacy and intentions allowed them to look towards role models, based on perceived similarity, prevalence, proximity, and, trust. Role models mostly consisted of family, peers, mentors, academics and symbolic figures. The entrepreneurial women recalled learning interactions with their role model, acquired skills to perform the observed behaviour, and received consistent feedback from mentors. Both direct and vicarious reinforcement enabled them to pursue their entrepreneurial endeavours.
\end{abstract}

Keywords: Vicarious learning, women entrepreneurs, FATA, Pakistan

\section{Introduction}

The social cognitive theory by Bandura (1977) suggests that vicarious learning involves observation of a role model's behaviour as a source of learning rather than learning through performing the action and exploring all possible outcomes (Manz \& Sims Jr, 1981). The role models within the individuals' surrounding include family members, teachers, friends and television characters (Connolly, 2017). This study aims to understand the vicarious learning of women entrepreneurs through role models in a backward tribal area of Pakistan. The purpose is to contribute a different perspective to the Learning and Entrepreneurship field as literature is mostly based on western perspective (Tariq, 2016).

Aubert (2014) noted that women entrepreneurs often set the direction of their business through role models. Vicarious learning is significant for entrepreneurs op-

1MS Scholar, National University of Sciences and Technology, Pakistan. Email: marium.hina@gmail.com 2 Assistant Professor, National University of Sciences and Technology, Pakistan.

Email: zunaira.saqib@nbs.nust.edu.pk

3 Assistant Professor, National University of Sciences and Technology, Pakistan.

Email: maria.khan@nbs.nust.edu.pk

\section{ARTICLE HISTORY}

26 Mar, 2019 Submission Received

23 May, 2019 First Review

06 Sep, 2019 Second Review

23 Nov, 2019 Third Review

05 Dec, 2019 Accepted 
erating with inadequate resources, capital and information. Instead of reinventing the wheel individual can increase their efficiency and move up in their learning curve by learning from others' successful and failed experiences (Kc, Staats, \& Gino, 2013). This study targets women belonging to the Federally Administered Tribal Areas (FATA), Pakistan, who possess inadequate skills, market opportunities and operate within social and cultural restraints with limited access to resources (Bari, 2000). Zozimo, Jack, and Hamilton (2017) noted that the social perspective to interpret entrepreneurial learning is still developing and interpretation about individuals' learning from others requires more in-depth research. Rae and Wang (2015) discussed that among other developing countries; Pakistan, despite experiencing vulnerable circumstances, is showing entrepreneurial development thus; making it essential to investigate how its entrepreneurs, operating within capricious environment, learn. Furthermore, positivist research paradigm is frequently used for women entrepreneurship research (Yadav \& Unni, 2016) therefore, contemporary research must employ in-depth qualitative approaches in order to closely examine what drives women to engage in their own entrepreneurial ventures. This study uses qualitative methodology to explore how FATA women entrepreneurs learn by observing their role models.

The study is very significant both for the literature and the practitioners. Authors have called in future researchers to explore how the process of vicarious learning unfolds in different situations (Myers, 2018). The literature has called in for future research to understand the motivation and values of entrepreneurs and how they learn (Abecassis-Moedas, Sguera, \& Ettlie, 2016; Choi, Hecht, Tafkov, \& Towry, 2015; Yitshaki \& Kropp, 2016). Thus, this study contributes to these gaps and helps understand the learning process of FATA women entrepreneurs. From the practitioners' perspective, it is important to note that most startups fail or their performance declines when a nascent entrepreneur launches business without experienced entrepreneurs' consultation (St-Jean \& Mathieu, 2015). This study explores vicarious learning in entrepreneurial context to understand how entrepreneurs learn and develop business skills through role models' assistance. This research highlights role models' importance in entrepreneurship by providing insights to policy makers, non-profit sector and business institutions to acknowledge the significance of facilitating vicarious learning from competent entrepreneurial role models and initiate projects and policies to promote and develop an enabling environment for tribal women entrepreneurs by ensuring role models' availability.

\section{Literature Review}

\subsection{Women entrepreneurs in FATA}

In 2018 Government of Pakistan declared merger of FATA with Khyber Pakh- 
tunkhwa (KP). FATA constituted of seven tribal agencies, which are now divisions of KP, including Khyber, Orakzai, Kurram, Mohamand, Bajaur, Waziristan and Malakand (Akbar, 2010). Since 2001, FATA has been victim of war on terror, economic meltdown, deteriorating law and order situation, and challenges of internal displacement. However, there is also rise in entrepreneurial endeavour which hopes to address extremism and will ultimately bring peace and prosperity (Muhammad, Akbar, \& Dalziel, 2011).

Women in tribal areas operate within financial constraints, limited health facilities, social mobility, and educational opportunities (AdeelAnjum, Khan, Raza, \& Fatima, 2012). Their legal rights are undermined as they are not entitled to inherit family property (Bari, 2000). Numerous governmental and non-profit organizations aim to empower FATA women through development projects providing vocational trainings and microcredit schemes so that they may acquire an independent financial position to engage in entrepreneurship ventures (Akbar, 2010).

Hanif, Meryem, Rao, and Nawaz (2017) noted that Pakistani women entrepreneurs mostly own home based businesses where financial matters are habitually dealt by male family members. One of the reasons for home based businesses is that the traditional Pukhtoon women (in FATA) are, indiscernible in their unique social settings with restricted social mobility (Azam Roomi \& Harrison, 2010). Therefore, the vocational trainings arranged for these women emphasise on imparting skills that can enable them to work from home. These skills include tailoring, jewellery making and handicrafts. It is suggested that many times these initiatives are unsuccessful due to lack of support from the male members of the community. The Pakistani culture predominately require women to hold the responsibility of family care (Rehman \& Azam Roomi, 2012). It is a challenge for developmental sector organizations to create awareness among these regions that women can play a role in the financial stability of the family as well. Moreover, FATA women lack education and exposure which results in low confidence which impedes their intention of opting for a business. Gohar, Rauf, and Abrar (2011) noted that Pukhtoon women entrepreneurs require male family members' assistance due to self-doubt to take on entrepreneurial endeavours in a male dominated society.

\subsection{Entrepreneurial learning of women}

Entrepreneurial learning is an activity in which an entrepreneur strengthens their beliefs about certain behaviours and actions that generate positive results (Moustaghfir \& Schiuma, 2013). Although Pakistani women consider business knowledge imperative for entrepreneurial success, majority of rural Pakistani women lack basic literacy hence making it a challenge to learn business knowledge (Azam Roomi \& 
Harrison, 2010).

While the research on entrepreneurial learning of women emphasise on self-directedness of learning (Abrar, Rauf, \& Gohar, 2011), it also meaningfully relies on significant others in the social relationships. Wells (2014) emphasised that social interaction is valuable for women's business growth as they develop contacts and relationships in a social circle. Ekanem (2015) also confirmed that women learned through mentors and informal networks.

\subsection{Vicarious learning and entrepreneurship}

Individuals learn vicariously when they observe role models' behaviour and its consequences. It enables them to avoid costly mistakes. Vicarious learning comprises of four interconnected components: Attentional, Retention, Motor Reproduction, and Motivational processes. The theory defines attentional process to be individuals paying attention to modelled behaviour. It is influenced by the characteristics of modelled behaviour and the observer. The retention process includes depiction of role model's behaviour in observer's memory. Individuals unable to recall the observed action or event cannot derive influence from it. The motor reproduction process refers to observer's capabilities that enable performance of desired modelled behaviour. They also require consistent practice and role models' feedback. Lastly, the motivational process suggests that reward influences observer to successfully perform desired behaviours and avoid those that result in punishment (Bandura, 1977; Connolly, 2017; Huber, 2013; Miller \& Dollard, 1941; Schunk, 2012).

Research emphasizes that women entrepreneurs' learning and development largely stems from multiple sources including family, friends (Chlosta, Patzelt, Klein, \& Dormann, 2012; Ekanem, 2015), teachers (Roberts, 2010), mentors (Ozgen \& Baron, 2007), peer groups (Liñán, Urbano, \& Guerrero, 2011), and symbolic models (Connolly, 2017; Newbery, Lean, Moizer, \& Haddoud, 2018). This research aims to understand how FATA women entrepreneurs acquire role model's behaviour and how they put this behaviour into action.

Vicarious learning's components describe learning through observing role models. Attention and retention subcomponents control modelled behaviours' acquisition. Motor reproduction and incentive controls behaviour performance learned by observing the role model (Bandura \& Jeffrey, 1973). The model is represented below in a graphical format and will be used to carry out the research.

This study explores how FATA women entrepreneurs learn vicariously through 
Vicarious Learning

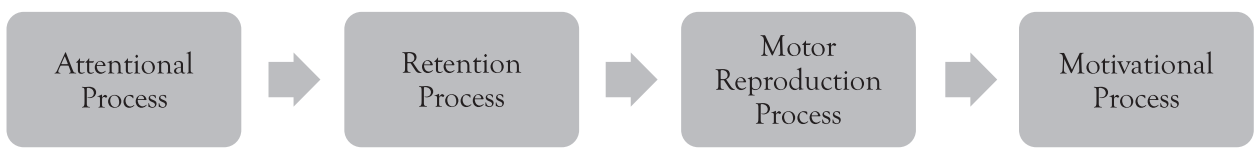

Figure 1: Vicarious Learning

observing their role models? The main research question is divided into two sub-questions.

1. How FATA women entrepreneurs acquire role model's behaviour?

2. How FATA women entrepreneurs perform the behaviour learned by observing the role model?

\section{Methods}

This research follows the rules of interpretivism which considers no single reality and considers a phenomena's interpretations to be manifold (Merriam \& Tisdell, 2015). The methodology suggests that knowledge of reality is socially constructed by humans (Burrell \& Morgan, 1979) within a cultural setting through social interactions (Cohen \& Crabtree, 2008). This research captures multiple interpretations of FATA women entrepreneurs' vicarious learning which derives influence from culture as they construct realities through social interaction. In interpretivism, subjects and researcher are interdependent throughout the research process and the researcher seeks new insights through the subjects (Hudson \& Ozanne, 1988). In this study, the researchers mutually constructed reality with the subjects and developed interpretation of vicarious learning with women entrepreneurs. Qualitative research was selected as it is a specific belief system, essentially contingent upon observing people in their domain, interacting with them in their specific mode of communication (Kirk, Miller, \& Miller, 1986). The researchers studied FATA women entrepreneurs within their context, interacted with them in Pashto (local language) and considered socio-cultural sensitivities. The data collection was made possible due to the gender of the researchers. It was not possible, otherwise, to interact with these women as they operate within a strict conservative society.

One to one semi-structured interviews were conducted with FATA women and three major organizations in Peshawar. The organisations in question are involved in extending support to FATA women entrepreneurs. The organisations' opinions were taken to explore the nature of FATA women's entrepreneurial activities. It enhanced the interview guide, facilitated respondents' identification for interviews, 
and, interpretation of their responses. This study prepared two interview guides. Respondents' interview guide has a small structured section to gather specific business information (business name, area of operation, industry, employees etc.) whereas the rest contained open-ended questions for in-depth probing. It included questions about their entrepreneurial journey and their interaction with role models which resulted in learning significantly used in the business. Additional questions arise from the discourse between researcher and participant (Flick, 2009). Similarly, probing questions emerged from the conversation which were different in all interviews based on the varying level of expertise, exposure and education.

Data was analysed by using thematic analysis, a highly flexible approach (King, 2004). According to (Braun \& Clarke, 2006), an in-depth qualitative data description emerges from this valuable analysis tool which identifies common patterns emerging from interview data (DeSantis \& Ugarriza, 2000); hence, in-depth data description explaining subjects' learning process was possible. This tool enables the researcher to analyse subjects' multiple perspectives and capture the emerging concepts therefore; it is suited to investigate different interpretations of FATA women entrepreneurs' learning through role models. The audio recordings of interviews were transcribed in detail to capture subjects' responses and were translated from Pashto to English for thematic analysis.

\subsection{Subject selection}

Purposeful sampling, which focuses on small and specific subjects for phenomenon's in-depth interpretation was used. According to Creswell, Klassen, Plano Clark, and Smith (2011) purposeful sampling identifies and selects individuals that are experienced and knowledgeable about the phenomenon.

The sample was selected based on expert opinion (Ponelis, 2015) of the three organisations. These organizations, through their various projects, provide skill and business trainings to FATA women. They have maintained a record of the FATA women who participated in these trainings and started their businesses. This information assisted in locating potential respondents for interviews. In one recent women empowerment project (in one of the three organisations), there were 360 beneficiaries, of which 80 women availed loans to establish their businesses (S. Noor, Personal Communication, April 5, 2018). However, only 10 women actively started their businesses, out of which six agreed for in depth interviews ${ }^{4}$. Some of the respondents were available in Peshawar city while travel was required to FATA to interview others.

Due to limited access to FATA and its unstable security, this study conducted six

4 Names of respondents and organizational personnel have been changed to maintain confidentiality 
in-depth interviews. According to McCracken (1988) in-depth interviews with few respondents are suitable rather than a large sample providing an overview. Moreover, purposeful sampling was considered appropriate because it identifies and selects information rich cases to effectively utilize inadequate resources. Apart from respondents' relevance, purposeful sampling also considers their compliance to participate in the research process, availability and the ability to communicate perspectives and experiences in a coherent and thoughtful way (Bernard, 2002; Spradley, 1979). Due to social and cultural boundaries in Pukhtoon society, few women were accessible who gave their consent to participate in the research and were able to communicate effectively.

The details of respondents are summarized in the table below.

Table 1: Subjects Profile

\begin{tabular}{|c|c|c|c|c|c|c|c|}
\hline \multirow{3}{*}{$\begin{array}{l}\text { Personal } \\
\text { Profile }\end{array}$} & Name & Noreen & Urooj & Sana & Kanwal & Irum & Amna \\
\hline & Area & $\begin{array}{l}\text { Bara, } \\
\text { Khyber } \\
\text { Agency }\end{array}$ & $\begin{array}{l}\text { Parachi- } \\
\text { nar (Tal) }\end{array}$ & $\begin{array}{l}\text { Khyber } \\
\text { Agency }\end{array}$ & Dir & $\begin{array}{l}\text { Landi } \\
\text { Kotal }\end{array}$ & $\begin{array}{l}\text { Landi } \\
\text { Kotal }\end{array}$ \\
\hline & Education & $\begin{array}{c}\text { Masters } \\
\text { (Urdu) }\end{array}$ & $\begin{array}{l}\text { Masters } \\
\text { (Urdu, } \\
\text { Islamiat) }\end{array}$ & $\begin{array}{c}\text { Masters } \\
\text { (Economics) }\end{array}$ & Bachelors & B.A. & $\begin{array}{l}\text { Able } \\
\text { to read } \\
\text { Quran }\end{array}$ \\
\hline \multirow[t]{4}{*}{$\begin{array}{l}\text { Business } \\
\text { Profile }\end{array}$} & Industry & $\begin{array}{l}\text { Antique } \\
\text { Jewellery }\end{array}$ & $\begin{array}{l}\text { Leather } \\
\text { Accesso- } \\
\text { ries }\end{array}$ & $\begin{array}{c}\text { Dress } \\
\text { designing }\end{array}$ & $\begin{array}{c}\text { Jewellery, } \\
\text { Herbal } \\
\text { Shampoo } \\
\text { and Oil }\end{array}$ & Tailoring & Peddler \\
\hline & $\begin{array}{l}\text { Business } \\
\text { Location }\end{array}$ & Peshawar & Bannu & Peshawar & Peshawar & $\begin{array}{l}\text { Landi } \\
\text { Kotal }\end{array}$ & $\begin{array}{l}\text { Landi } \\
\text { Kotal }\end{array}$ \\
\hline & $\begin{array}{l}\text { Business } \\
\text { Initiated }\end{array}$ & 2013 & 2015 & 1991 & 2014 & 2005 & 2014 \\
\hline & Employees & 3 & 12 & 150 & None & None & None \\
\hline
\end{tabular}

\subsection{Researcher's biases}

According to Altheide and Johnson (1994), researcher is required to clearly describe their biases in detail to minimize its effect and it also adds to the validity of the interpretation and findings of the qualitative inquiry. The researcher's point of views have been discussed in the table below. 
Table 2: Researcher's Point of Views

\begin{tabular}{|c|}
\hline Researcher's Assumptions \\
\hline $\begin{array}{l}\text { Subjects will be mostly illiterate however, it will not affect their participation in research rather it } \\
\text { will bring variation to the findings. Moreover, it is unlikely to find variation in their type of work } \\
\text { because FATA women are mostly given sewing machines and are involved in vocational trainings. } \\
\text { They mostly display their crafts through exhibitions. }\end{array}$ \\
\hline Researcher's Bias \\
\hline $\begin{array}{l}\text { Researcher's personal belief and insights from the literature shows that entrepreneurship is appro- } \\
\text { priate for tribal women due to their resilience, strength and agility. }\end{array}$ \\
\hline
\end{tabular}

\section{Findings and Analysis}

The data is reported by dividing it in four components describing vicarious learning process.

\subsection{Attention}

Attentional processes refer to the degree to which an individual notice and derives influence from the modelled action or behaviour (Connolly, 2017). Both the characteristics of the observer and role model impact the attentional process. The likelihood that an individual will observe and imitate behaviour largely depends on role models' characteristics. Moreover, observer's skills also significantly impact vicarious learning. The following section is divided into observer's attributes and role models' attributes to understand the attention process.

\subsubsection{Observer attributes}

Respondents' entrepreneurial intentions and self-efficacy enabled them to locate relevant role models which significantly influenced their business goals. They showed interest and determination in doing business regardless of skills, resources and risks at hand. It led to their willingness to learn from others and frequently availed learning opportunities through business and skill trainings. Moreover, respondents had a strong belief and confidence in their abilities to successfully start business and this self-efficacy led to an active search for peer role models within their surroundings. One respondent shared her aspirations:

"I am always learning new things and brining variations in my work ... [at WCCIPD one of the three organisations] I saw a lot of successful business women, and I thought [I have work experience as well] why not take my business further. I had firm belief in my abilities ... Yesterday I met a young girl from Hangu who owns a home industry so I thought if she can 
do this, why not me." - Noreen

Apart from entrepreneurial intentions a higher level of confidence and belief in abilities enabled women to relate with their models and since they have a living example to follow in their environment therefore it strengthens their entrepreneurial intentions. Despite socio-cultural restrictions, respondents still showed interest in learning from relevant role models available around them, including outside their home. It seemed that most of the respondents' role models were other women, due to conservative society which discouraged mix gender gathering. However, despite this, some women showed resilience. One of the respondents contacted various organizations in Peshawar to seek mentors.

\subsubsection{Role models' attributes}

Some respondents had family role models from whom they frequently learned skills and gathered relevant knowledge required in establishing business. Mothers were found to be more effective role models. One respondent shared;

"I used to see my mother making jewellery so I also started making it ... my mother taught us that whatever you do for yourself, you should do the same for others. I make shampoos at home, I use it myself and sell it as well" -Kanwal

The prevalence of mother as a frequent role model for respondents is due to cultural constraints women mostly stay inside home and interact with mothers.

A strong patriarchal Pashtun culture prevails in FATA, where women mostly stay in a veil and are restricted to the confines of their family and household. One respondent who started business 15 years back while living in FATA, perceived that any correspondence with men other than family members will invoke anger and will be considered negative. After registering with business development organizations, she observed other business women who interacted with male business individuals had an advantage. It enabled her to acknowledge the significance of interaction with businessmen and gave her confidence to overcome the fear of interacting with them.

The three organisations, $\mathrm{KK}^{6}$, WCCIPD ${ }^{7}$ and $\mathrm{SMEDA}^{8}$, provided formal mentoring to assist women in evaluating potential business opportunities, training for women entrepreneurs' skill development, and business awareness. They arranged events and industry tours that enabled women to learn from others. The interview with Director Programs at KK revealed that;

6 Khwendo-Kor - a non-profit, non-partisan organization set up to guide women to take practical steps for the betterment of themselves and their families.

7 Women Chamber of Commerce $\mathcal{E}$ Industry Peshawar Division

8 Small and Medium Enterprises Development Authority 
"We arrange visits; as learning through practical exposure is very valuable. We took them to a production unit in Islamabad. ... they saw the entire value chain and some of them got inspiration from that. We make them interact with people through industry visits too"

Again, due to the conservative surrounding the women had no exposure to how formal businesses worked and how they could take their own business idea forward. The much needed exposure of industrial visits was provided by the three organisations to help women take inspirations. It was apparent that the organizations played a major role in enabling these women entrepreneurs to learn from experience of others. A respondent living in FATA was the first and only business woman in her family and seldom found role models in her environment. After getting registered with WCCIPD, she got the opportunity to attend seminars and conferences. She expressed excitement about these meet ups which was a great source of learning for someone who has been operating business within the social and cultural constraints of the FATA region. Moreover, the national and international exhibitions provided a networking opportunity with the business fraternity;

"they [WCCIPD] connect us with people that I can never imagine to meet. I met business people from Iran, SriLanka, Nepal and Maldives. We share information about countries and our businesses" - Urooj

Bandura (1986) suggested that observers will learn from role models based on distinctiveness, functional utility and perceived similarity. It seemed that FATA women considered peers already doing business, as distinct role models. These peers also provided functional utility by providing information about new product ideas. One respondent's products reached international markets through a peer's knowledge and contacts. In one of the business exhibitions, arranged by business development organizations, one of the respondents was approached by an Afghan businessman to introduce her products in $\mathrm{Kabul}^{9}$. He advised her to increase the product bottles size as in Kabul; they have extended families and buy stock in bulk. It seemed that respondents living in FATA were particularly affected by peers in their environment due to perceived similarity. Their expertise, experiences and assistance were considered valuable. One respondent could relate to a peer in her village who was a widow like her and earned to support her children. Another respondent living in Peshawar, mentioned learning from a television character not only based on perceived similarity, but also due to lack of real-life entrepreneurial role models within her environment. She got inspiration and motivation to do business by a TV character - a business woman who wore an Abaya ${ }^{10}$ and had an office. While initially the women seek same gender role models, with the much needed exposure they started taking inspiration

9 Capital city of Afghanistan

10 A full-length outer garment worn by some Muslim women 
from opposite gender as well.

Respondents with better access to education paid attention to academic peers. One respondent, a BBA student, utilized her university Professors' knowledge for pricing products. She mentioned that customers pay for products' value and she has learned to effectively price her unique products by charging for the value that she provides. This is also supported by Saeed, Muffatto, and Yousafzai (2014) suggesting that University's support impacts and increases students' entrepreneurial intentions. One respondent shared that initially she knew little about how to place products in shops and an experienced shopkeeper advised her to keep a receipt book. Another respondent living in FATA was assisted by her village's bus driver to locate markets in city based on customer demand.

It seemed that most respondents' entrepreneurial intentions and self-efficacy enabled them to seek role models and trainers for effective learning. Their vicarious learning was initiated by noticing role models' significant attributes. Respondents' preferred models based on expertise, perceived similarly and frequency of interaction. In collectivist cultures, family is given importance which was evident in respondents' leaning. The analysis showed unique learning experiences from bus drivers and shopkeepers. This is true in case of FATA as well where elders' advice is respected and trusted because of their experience which provides an enabling learning environment for respondents.

\subsection{Retention}

This theme refers to the extent to which respondents retained observed behaviour. During data collection, some respondents shared their interaction with role models with vivid details. One respondent gave a detailed account about time spent with her peer where she accompanied her daily to the market and closely observed her behaviours and actions. There are various possible explanations for this recall of past events with clarity. First, the respondent, being a disadvantaged widow, was interested in observing how her peer earned a decent living. Her focused attention on the activities enabled her to retain information for longer period. Also the respondent simultaneously started working along with peer interaction. Consequently, new information was put to use instantly and was practiced, making it part of the permanent memory.

"I used to shadow [the role model] and observed where she buys stuff from. I also observed how she negotiates with shopkeepers" - Amna

Individuals working with real life role models get instant feedback because they were not only observing but also interacting with the role model. Another respondent not only remembered her learning interaction with the role model, but also the 
product information she collected. One possible reason is that respondents frequently collect relevant information and compare it with their own.

"Once I asked a woman who has [same products] about what she uses in her products. She said she used 5-6 herbs and eggs, discarded the yolk and boiled egg whites for the [product]. I also asked her for more information, she said that she throws away the herbs and leaves some powder and adds colour" - Kanwal

This also showed that when an individual is interested in something they tend to remember the information for a longer period of time. However, some respondents recalled their learning experiences after probing questions were used. One possibility of this could be the inability to acknowledge learning from others. When newly learned behaviour from role model's advice or actions is performed, it becomes part of their personal experience; hence, making the respondents believe it is their own ability.

\subsection{Motor reproduction}

According to Cherry (2012) paying attention to the role model and retaining the modelled behaviour is followed by observed behaviour's performance. Motor reproduction describes how an observer reproduces the observed behaviour or action. It is described in figure below.

\subsubsection{Observers' capabilities}

It refers to respondents' capabilities which enable them to act upon role models' recommendations. To effectively perform observed behaviour, an individual needs a

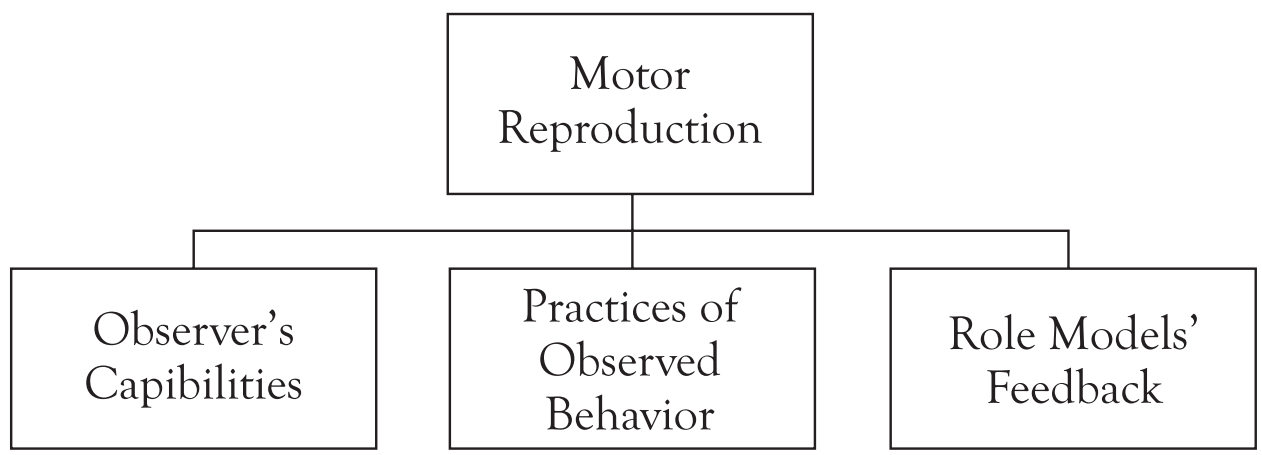

Figure 2: Motor Reproduction 
certain level of skill as a precondition (Connolly, 2017). The prerequisite information about herbs that a respondent gathered through Internet enabled her to effectively seek role models assistance about herbal products. According to her, Internet provided access to knowledge reservoirs, but the experience of others helped accelerate the process of developing herbal formulas for products. Among the six women interviewed, four had regular access to internet and suggested that WCCIPD had established a WhatsApp ${ }^{11}$ group where there was a regular exchange of ideas and information. This enhanced their learning further. Respondents' creativity helped them to incorporate their unique ideas with the skills instructed by trainers which resulted in efficient learning. Few respondents already possessed certain skill level and were able to quickly learn from advanced skill trainings. A respondent shared that she knew the basics of sewing clothes which reduced the complexity of advanced trainings she took to learn finishing of leather products.

"I learned leather cutting on the very first day of the training session because I am already an expert in cutting and sewing clothes. There is [similar] measurement in leather and clothes ... I could cut it easily" - Urooj

The basic skill level enabled an individual to make better sense of the observed behaviour as it made it easy to apply the behaviour and also to move towards a higher level of skill.

\subsubsection{Practice of observed behaviour}

An individual is able to enhance their skills, when the observed behaviour is practiced (Cherry, 2012). Most respondents mentioned improving skills through repeated practice. They acknowledged that initially their product lacked finesse but practice helped refine it. Another respondent repeatedly experimented with her herbal products until she got the desired effect. One of the respondents shared;

"After learning sewing from my mother, I made small mistakes but I [practiced it] again and again ... now if you give me any design, I can easily make it" - Irum

The learning through observation emphasise that practice of the observed behaviour ensured that the behaviour was performed with precision. The daily practice assured that behaviour was retained and improved each passing day.

\subsubsection{Role models' feedback}

One respondent living in FATA had more interactive learning experience when she accompanied her peer role model to the market as she could ask questions and

11 A freeware and cross-platform messaging and Voice over IP service that enables the exchange of text, voice / video calls and media 
got feedback in real-time. Some got consistent feedback from expert trainers on improving product finishing. Mentors at SMEDA also regularly provided positive recommendations to respondents for product refinement. One respondent shared;

"There is a person in SMEDA who provides support and guidance. I usually take advice from him. He also develops linkages and invites us for trainings ... when I make products, he comes to exhibitions and gives me feedback on product presentation as well. These people are experts; they know both, customers and business" - Noreen

Mentors' feedback enabled entrepreneurs to apply corrective action. KK, SMEDA and WCCIPD had proper feedback mechanisms to strengthen women's entrepreneurial skills. KK's trainers frequently visited trainees living in FATA to provide feedback. This feedback was also important to keep these women engaged and motivated to start and maintain their businesses.

\subsection{Motivation}

Motivation enables an individual to perform certain behaviours and without it, there is less chance for behaviour imitation. Bandura (1986) identifies three types of reinforcement discussed in the literature of which two emerged in the interviews. This theme is demonstrated in the figure below.

\subsubsection{Direct reinforcement}

It refers to role models' encouragement that helps reinforce learned behaviours.

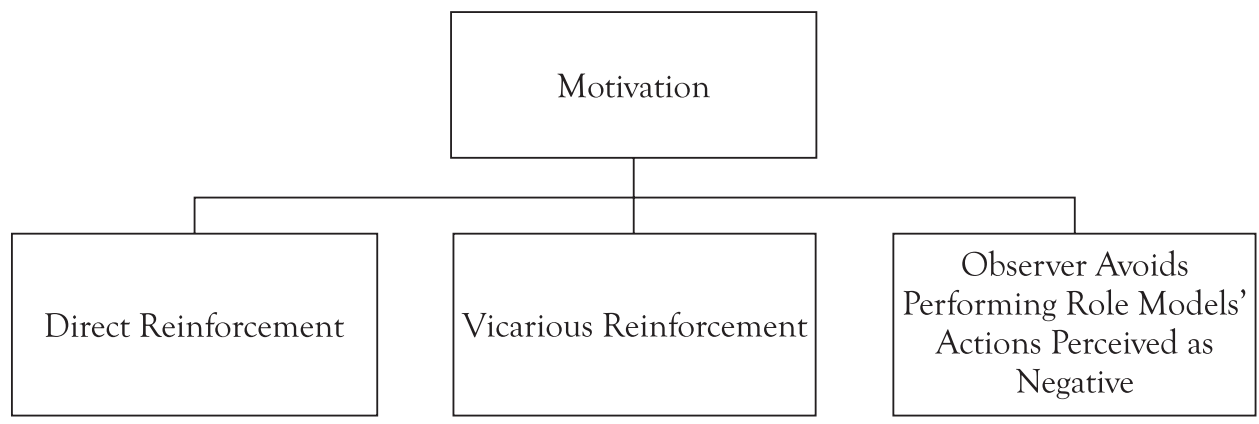

Figure 3: Motivation

Two respondents mentioned that their mentors praised improvement in their products which motivated them to work even harder. One described;

"[The role model] at SMEDA usually comes on exhibitions, sees my products and praises my efforts and encourages further refinement ... this appreciation for my 
efforts increases my motivation” -Noreen

The mentors provided by organizations had an advantage that they give feedback in the real time. When they monitor the performance and reward them with appreciation it encouraged the entrepreneur to perform much better.

\subsubsection{Vicarious reinforcement}

Vicarious Reinforcement refers to individuals being motivated to learn from successful examples (Bandura, 1977). Two respondents got an opportunity to observe successful entrepreneurs getting rewarded for certain behaviour which strengthened their conviction to follow their example. Organizations arranged seminars in which successful entrepreneurs shared their stories and experience which provided respondents the motivation to be persistent. Moreover, peer role models' success and prosperity strengthened the respondents' entrepreneurial resolve. One respondent shared how her intentions were vicariously reinforced.

"[The mentor's] children were young when she got widowed. It has been 15 years now and she is doing [the business] successfully and she paid for her children's weddings, renovated her house and even facilitated her children to start businesses. She invited me to start [my business] with her so that I may be able to fulfil my children's need" - Amna

While the learning from success of other entrepreneurs was common it also seemed that the FATA women also learned from their role models failure as well. The entrepreneurs avoided repeating the mistakes that their role model made. The reward or punishment that the role model received also reinforced the behaviour. For example, one respondent learnt from the mistakes of their role model and avoided that behaviour. She explained:

"The [mentor] did not use herbal oil and shampoo the way I use mine. Their father is a hakeem ${ }^{12}$ but they don't believe their products to be effective ... I said that my shampoos [consistency] isn't thick, they told me to add [chemicals]. I said we don't use chemicals [to differentiate from mainstream products] ... My products only have herbal ingredients" - Kanwal

Similarly, another respondent had been observing her peer model and openly acknowledged the role model's positive attributes which she adopted; however, she refrained from the role models negative attributes. She shared;

"[My role model] is new in business but she has progressed as she is confident, but people can get irritated from her because if she believes someone is useful, she becomes a bit too imposing" -Noreen

12 a physician who develops traditional herbal remedies for medicinal purpose 
The analysis suggested that respondents were thoroughly motivated by role models' behaviour that resulted in entrepreneurial success. The replication of an observed action or behaviour was more likely to be imitated due to reward value attached with it. Women were motivated by success of those similar to themselves which strengthened their entrepreneurial intentions.

\subsection{Issues in learning from others}

Literature mostly highlights how vicarious learning influences entrepreneurs' attitude (Liñán et al., 2011), self-efficacy (Bosma, Hessels, Schutjens, Praag, \& Verheul, 2012), career selection (Zapkau, Schwens, Steinmetz, \& Kabst, 2015), and intentions (Vuorio, Puumalainen, \& Fellnhofer, 2018); however, inadequate research exists that discusses potential problems occurring in vicarious learning which reduces its impact. The emerging findings in this study's analysis highlight respondents' challenging experiences while learning from others.

Some respondents described women role models as selfish who misguided them. Respondents living in FATA, lacked business knowledge at the start of their venture. One respondent utilized the expertise of others but felt mostly deceived. This learning from the experience of others resulted in financial instability and frequent business failures which made her vulnerable. She explained;

"Everybody gives you different advice [about business] and in most cases, it is wrong and creates problems ... Nowadays, people aren't honest about their mistakes so that you may learn from them." - Urooj

Since the initial stages of the business are most vulnerable, the women entrepreneurs seek advice of role models to avoid failure. However the poor advice created uncertainties and doubt leading to minimization of entrepreneurial intentions. The role models refrained from sharing their negative experiences in business because it exposed their vulnerability and hence gave poor advice.

Some respondents' learning was reduced due to interaction with role models. One respondent had strong self-belief and relied less on role models. Her vocational trainings provided a skill set that supported her business and her talent and creativity reduced her dependency to learn from others. She described her interaction with mentors;

"[SMEDA] asked me repeatedly to increase bottle size and reduce the price. I did not want to because I have invested a lot in my products ... It is the customers' mistake that they are attracted to packaging [of mainstream products]. The chemical in [mainstream shampoos] damage hair. There is no one [except me] who produces herbal products that show results in 


\section{5 days" - Kanwal}

The above quote shows that interaction between the mentor and entrepreneur was frequent but the effectiveness was undermined because the entrepreneurs was not ready to listen to the advice rather they followed what they believed in. Although, most respondents consistently learned from role models; certain information, ideas and assistance provided by mentors were ineffective due to difference of opinion.

The summary of this research's findings are provided in table below:

\section{Discussion}

This study aimed to explore FATA women entrepreneurs' vicarious learning to

Table 3: Data Analysis Findings

\begin{tabular}{|c|c|}
\hline \multicolumn{2}{|c|}{ Attention } \\
\hline Observer Attributes & $\begin{array}{c}\text { Respondents' entrepreneurial intentions and } \\
\text { self-efficacy enabled them to pay attention to } \\
\text { role models. }\end{array}$ \\
\hline Role models' Attributes & $\begin{array}{c}\text { Respondents mostly possessed family models; } \\
\text { due to proximity, prevalence and trust whereas } \\
\text { mentor models' expertise caught their attention. } \\
\text { Peer models' distinctiveness, functional utility } \\
\text { and perceived similarity were of interest to } \\
\text { them. }\end{array}$ \\
\hline Respondents shared their vicarious learning experiences which proved that new actions, behaviour \\
and skills were learned.
\end{tabular}




\begin{tabular}{|c|c|}
\hline Direct Reinforcement & $\begin{array}{c}\text { Mentors praised their skills and improvement in } \\
\text { products. }\end{array}$ \\
\hline Vicarious Reinforcement & $\begin{array}{c}\text { Respondents observed successful entrepreneurs } \\
\text { getting rewarded for a particular action which } \\
\text { strengthened their conviction to follow their } \\
\text { examples in the hope for same rewards. }\end{array}$ \\
\hline $\begin{array}{c}\text { Observer avoids performing role models' actions } \\
\text { perceived as negative }\end{array}$ & $\begin{array}{c}\text { Respondents learned from peer models' } \\
\text { negative aspects where one perceived peers' } \\
\text { approaches as unsuitable as compared to the } \\
\text { customer value she wanted to deliver. }\end{array}$ \\
\hline Role models reduce vicarious learning & $\begin{array}{c}\text { Due to lack of business knowledge, they utilized } \\
\text { others' expertise but were mostly misguided. }\end{array}$ \\
\hline Observers' role in minimizing vicarious learning & $\begin{array}{c}\text { Strong belief in abilities and difference of opin- } \\
\text { ion with mentors resulted in ineffectiveness of } \\
\text { this relationship. }\end{array}$ \\
\hline
\end{tabular}

understand how they learned through role models. Following discussion interprets research's findings in light with the literature.

\subsection{Participation in vicarious learning}

Gibb (2002) noted that individuals initiating small businesses usually learn by performing, trial and error, imitating, mistakes, solving problems, exploiting opportunities, peers, and, the feedback of customers and suppliers. This study's findings suggest that educated women used vicarious learning in combination with other learning sources whereas the uneducated women living in FATA vicariously learned from peers. It shows preference of vicarious learning when education and other learning sources are unavailable.

\subsection{Attention}

Analysis revealed that FATA women's entrepreneurial intentions and self-efficacy enabled them to seek role models. Even though Sherazi and Zahra (2015) reported that Pakistani women's have low entrepreneurial intentions and self-efficacy, this study's findings showed respondents' strong belief in their abilities to attain business goals and courage to seek advice. Sherazi and Zahra (2015) studied urban women entrepreneurs who lacked confidence, business interest, and, considered it a masculine occupation due to insufficient family support, non-business education, limited access to male business circles and weak women business networks. In this study, however, respondents' motivation of initiating business stemmed from self-fulfilment, financial 
instability, and, insufficient employment opportunities. They had family and government support to pursue entrepreneurial endeavours. It confirms Boukamcha (2015) findings which suggested that entrepreneurial self-efficacy is higher for individuals who are frequently involved in entrepreneurial training initiatives. Same is reported by Maritz and Brown (2013) who noted that females demonstrating higher entrepreneurial self-efficacy resulted from their active participation in various entrepreneurial education trainings.

Entrialgo and Iglesias (2017) suggested that women's social network comprised of family members who assisted in opportunity recognition. Gohar et al. (2011) also confirmed that family context provided legitimacy to Pukhtoon women entrepreneurs. Since in Pashtun society, women are restricted to the confines of their household (Akbar, 2010), most suitable role models for respondents emerged from family based on proximity, trust and relevance. This study confirmed learning from family but also showed that FATA women pursued other learning opportunities whenever given a chance.

This research also helps in understanding respondents limited symbolic role models. First, Pakistani media insufficiently represents entrepreneurship (Ali, Lu, Cheng, \& Chaoge, 2012) which affects role models' availability, and second, in developing countries, women entrepreneur's access to certain media sources is constrained due to limited education, language, improper infrastructure, internet connectivity, and inadequate IT skills. Among the six women interviewed for this study, two did not have access to internet to begin with as they lived in remote regions of Pakistan. Consequently, this indirectly forced them to seek role models elsewhere, i.e. in their environment, based on perceived similarity and benefit. The other four women, who did have access to internet, had their learning from role models facilitated due to the exchange of information with their role models through the WCCIPD WhatsApp group as well as through general information acquired through informal use of the Internet. This behaviour is not uncommon, where entrepreneurs look towards online information in order to enhance their learning and access information about their products and markets; however, there are limitations on how much this may explain the behaviour of women entrepreneurs, especially in rural areas. (Davis, 2011) compared rural and urban women entrepreneurs in Canada, and found that when regular high-speed Internet isn't accessible, formal e-learning initiatives as well as access to a wider knowledge base limits how women entrepreneurs were able to develop their businesses. This explains how the women entrepreneurs in the remote areas preferred models that were immediately accessible in their environment. Thomas and Moisey (2006) also explained how informal learning on the Internet by women entrepreneurs may be beneficial however, its contribution to employee learning is mediated by so- 
cio-cultural factors including, access, cost as well as ability to interpret information gathered through online resources. Bosma et al. (2012) also reported that entrepreneurs preferred accessible role models and rarely possessed distant media models. This may justify why certain FATA women settled in cities didn't possess symbolic role models.

This study also confirmed that FATA women sought out mentors who had significant business expertise. SMEDA, KK and WCCIPD provided mentors and platform for women entrepreneurs to interact with others. Respondents reported that mentors helped them in overcoming business challenges and availing potential business opportunities. These organizations arranged skills and business trainings, seminars, workshops, industry visits, and business tours. These learning opportunities were important for FATA women entrepreneurs as they lacked exposure and learned through interaction with business community. Respondents living in settled areas availed these opportunities whereas due to mobility issues of women living in FATA; KK established vocational training centres at different regions in FATA.

Newbery et al. (2018) stated that social context offers ideal examples of different roles, actions and behaviours. Analysis showed that respondents learned through expertise of business peers, bus drivers, and, shopkeepers. Hanif et al. (2017) reported that there is insufficient peer support for Pakistani women entrepreneurs, which consequently limits learning through peer role models. On the contrary, FATA women in this study reported major peer support. In Pakistan, women's participation in entrepreneurship is still in its nascent stages due to social unacceptability; hence, environment provided limited business women but organizations were consistently helping in developing women entrepreneurship. FATA women's responses showed provision of a supportive environment which highlights women entrepreneurship's acceptance in Pakistani society.

Interestingly, majority of women showed no particular preference for role models' gender. It contradicts with the study of Markussen and Røed (2017) that showed individuals preference for same gender role models. Moreover, tribal women participated in activities with minimal mobility and least interaction with outside men (Mohsin, 2013). It is possible that organizations provided exposure enabled FATA women to acknowledge businessmen's expertise. This study showed that FATA women in settled areas believed in business men's support whereas financial instability of women living in FATA enabled them to overcome fear associated with male interaction. Thus, this study is able to bring to light new insights into how we understand women entrepreneurs' attentional processes in under-developed regions of the world.

\subsection{Retention}


Apart from paying attention to observed behaviour, it is important that observer is able to retrieve information for later reference (Cherry, 2012). In this study, respondents shared their vicarious learning experiences with vivid details; however, took time to share these events which were ingrained in their implicit memory. Carson, Gilmore, Perry, and Gronhaug (2001) describe implicit memory as an individual's prior experience used in actions without consciously recalling these experiences. It makes it difficult to describe how you learnt a certain skill as it results in new behaviours or skills that become part of individuals (Wager \& Cox, 2009).The study's findings showed that respondents' skills improved with practice and became embedded in their personal approach.

\subsection{Motor reproduction}

According to Bandura and Jeffrey (1973) in motor reproduction, observer requires physical and mental capabilities to perform the observed behaviour, consistent practice and role models' feedback enables them to enhance performance. This study's findings showed that skills of women settled in cities were more refined which further improved through learning with role models. However, skills of women living in FATA were not polished which later through trainings were improved. Respondents acknowledged that consistent practice of skills learned from mentors improved their products and have reached international markets. Moreover, vocational trainers provided feedback on products and updated them about latest market demands. This result is supported by Cox, Mueller, and Moss (2002) who states that instructor's positive feedback and encouragement ultimately increases individuals' self-efficacy.

\subsection{Motivation}

This study's results showed that respondents were motivated to learn from others' experiences. Connolly (2017) referred to motivation as an underlying element in vicarious learning. It is supported by evidence from in-depth data analysis.

First, in attentional processes, role model must be attractive enough to stimulate observer's attention and requires observer's interest while interacting with role model. Similarly, respondents reported interest in entrepreneurship and were particularly attracted to role models' expertise and success. Second, retention requires observer's motivation to retain behaviour in memory for future reference. Respondents reported learning events with vivid details. Third, observers' motivation in motor reproduction is evident in their practice of observed behaviour. Likewise, respondents reported consistent skill practice learned from trainers. Fourthly, motivation refer that observed behaviour's performance is contingent upon rewards associated with it which increases performance motivation. 
Findings showed respondents' direct reinforcement through mentors' appreciation. For vicarious reinforcement, respondents interacted with other business peers whose success provided motivation to pursue their entrepreneurial endeavours. According to Guiso, Pistaferri, and Schivardi (2015) peers create awareness and motivate entrepreneurs during initial business stages. In Pakistan, women entrepreneurship lack social acceptability resulting in few women role models, however, organizations provided trainings; arranged exhibitions, and assisted women in pursing national and international prospective markets.

According to Bandura (1991) values and beliefs emerge from social interaction as an amalgamation of family and social values. Respondents' values were different from role models; hence, it decreased their motivation to follow certain actions perceived as unsuitable. This finding is supported by Bandura (1991) that observer's personal standards are used to judge others behaviours which minimize the influence of modelling.

\subsection{Issues in vicarious learning}

FATA women entrepreneurs faced problems during learning from others' experiences. The issues influencing vicarious learning stemmed from both respondents and role models. Analysis showed that FATA women encountered negative experiences with the role models which minimized vicarious learning's impact. Initially in business, some respondents lacked information thus utilized the expertise of others which resulted in frequent business failures. Despite negative experiences, this study's respondents continued business and learning through others which showed their entrepreneurial resilience. It is supported by Bullough, Renko, and Abdelzaher (2017) that entrepreneurs' strong belief in their abilities raises their confidence to tackle business complexities and this self-efficacy increases resilience (Benight $\&$ Bandura, 2004). Nikolić, Jovanović, Nikolić, Mihajlović, and Schulte (2018) also suggested that small businesses often fail due to conditions under which they operate. They can be improved only by removing the obstacles that hinder growth and development of small businesses by developing the appropriate system of support for entrepreneurs.

Women educated and raised in cities possessed knowledge and family support which gave them strength to take on a challenging endeavour without fearing failure. Their personal experience built upon their skills and self-confidence was preferred over the learning from others' experience. During interaction with mentors, their self-confidence and self-belief influenced the learning process and resulted in conflicting opinions. Furthermore, due to availability of Internet and access to online knowledge bases including interaction with role models through social media, the learning process was enhanced to a certain degree whereby the women entrepreneurs 
were able to find better role models and cross-check business concepts to strengthen their self-efficacy.

BarNir, Watson, and Hutchins (2011) suggested that women's entrepreneurial self-efficacy derives strong influence from role models and mentoring relationships boosts self-confidence. However, this study's findings showed that respondents' self-confidence negatively influenced the impact of certain mentoring relationships by relying less on mentor's assistance. One potential justification could be that high self-efficacy enabled these women to evaluate which business approach is most suitable. Another potential justification is that respondents' cognition plays an important role where they decide appropriate behaviours. Research suggested that humans are not just a product of external environment and are solely guided by inner motives; rather, they possess an inherent ability to shape their behaviour. They continuously develop thinking patterns which helps to strategize behaviours suitable in uncertainty hence; their thoughts, beliefs, expectations and feelings influence their behaviour (Bandura, 1986, 1989). This could be one explanation why certain role models behaviours were not adapted by some respondents.

The study was able to contribute to literature through answering the call of researchers such as Jamali (2009) who emphasise the need to understand the entrepreneurial behaviour of women in developing countries, including Pakistan, with special emphasis on exploring their learning processes (Rae \& Wang, 2015). The study is also able to demonstrate the importance of self-efficacy and institutional support in shaping how women entrepreneurs of FATA, are able to learn and enhance their business ventures. Socio-cultural factors including family support and access to augmented services such as the Internet are shaping the manner in which these women are able to build their businesses to improve the life of their household. This study brings to light previously unexplored issues of women entrepreneurs in underdeveloped regions about which sources they perceive to be useful for learning including realising the importance of interacting with male business individuals as well as counting them as a more reliable source of information. Furthermore, the role of institutions such as KK, WCCIPD and SMEDA has allowed these women to understand the importance of a varied source of acquiring role models rather than just relying on immediate environment. This is especially interesting in the context of FATA women who operate in a society which scarcely allows them to interact with non-family males. This indicates some growth of societal values and has important policy implications for institutions as well as individuals regarding future development and enhancement of women entrepreneurial learning in under-developed regions. 


\section{Conclusion and Future Directions}

This study explored how FATA women entrepreneurs learn vicariously through its four components: attention, retention, motor reproduction and motivation. Attention and retention provided insights about the research question of how FATA women entrepreneurs acquire role model's behaviour. Motor reproduction and motivation answered the question of how FATA women entrepreneurs performed the behaviour learned through role model observation. Furthermore, emerging findings described how respondents and their role models minimized vicarious learning's impact.

The study contributes to theoretical, methodological and contextual gaps in the literature. It extended learning's social perspective by describing FATA women entrepreneurs' vicarious learning. This study's limitations highlight potential avenues for future inquiry. Individuals' experiences should be studied for longer period considering the on-going nature of learning process (Rae, 2000) whereas this study reported them as occurring in a retrospective manner due to limited time. Therefore, longitudinal case studies would be effective approach (Davidsson, 2005). Limited FATA women entrepreneurs and inaccessibility due to security concerns constrained sample size. In future large sample's availability will enhance study's generalizability. Moreover, to achieve triangulation, observations were impossible due to FATA's socio-cultural restrictions as such intrusion could have caused discomfort to participants.

Academicians, policy makers and practitioners are extending their interest to women's entrepreneurial progression in developing countries (Anggadwita \& Dhewanto, 2016). This study's results showed that respondents availed peer support and an enabling business environment. This possible development of entrepreneurial acceptability for Pakistani women requires further exploration by academicians. Moreover, another important area of investigation for future research is the findings that FATA women showed no particular preference for role models' gender. Despite regions' conservative value system these women had the support of family members in their business and the organizational support provided exposure enabling FATA women to acknowledge businessmen's expertise.

\section{References}

Abecassis-Moedas, C., Sguera, F., \& Ettlie, J. E. (2016). Observe, innovate, succeed: A learning perspective on innovation and the performance of entrepreneurial chefs. Journal of Business Research, 69(8), 2840-2848. doi:https://doi.org/10.1016/j.jbusres.2015.12.053

Abrar, A., Rauf, A., \& Gohar, M. (2011). Conceptualizing gender and entrepreneurial learning-a review of literature. Paper presented at the ICSB World Conference Proceedings. 
AdeelAnjum, M., Khan, N., Raza, S. A., \& Fatima, S. (2012). Problems and prospects of women entrepreneurs: A case study of Quetta-Pakistan. International Journal of Business and Social Science, 3(23).

Akbar, N. (2010). Women rights in FATA Pakistan: A critical review of NGOs' communication strategies for projects' implementation. Universitetet i Tromsø,

Ali, S., Lu, W., Cheng, C., \& Chaoge, L. (2012). Media inattention for entrepreneurship in Pakistan. European Journal of Business and Management, 4(18), 96-100.

Altheide, D. L., \& Johnson, J. M. (1994). Criteria for assessing interpretive validity in qualitative research. In Handbook of qualitative research. (pp. 485-499). Thousand Oaks, CA, US: Sage Publications, Inc.

Anggadwita, G., \& Dhewanto, W. (2016). Women's entrepreneurial intentions in micro and small enterprises (MSEs) in Indonesia: The influence of environmental factors on perceived behavioral control. Journal of Administrative and Business Studies, 1(1), 1-7.

Aubert, J. (2014). Women entrepreneur revolution: Ready! Set! Launch! : Balboa Press.

Azam Roomi, M., \& Harrison, P. (2010). Behind the veil: womenПonly entrepreneurship training in Pakistan. International Journal of Gender and Entrepreneurship, 2(2), 150-172. doi:doi: $10.1108 / 17566261011051017$

Bandura, A. (1977). Self-efficacy: Toward a unifying theory of behavioral change. Psychological Review, 84(2), 191-215. doi:10.1037/0033-295X.84.2.191

Bandura, A. (1986). Social foundations of thought and action. In D. Marks (Ed.), The health psychology reader (Vol. 1986). Englewood Cliffs, NJ.

Bandura, A. (1989). Human agency in social cognitive theory. American psychologist, 44(9), 1175.

Bandura, A. (1991). Social cognitive theory of self-regulation. Organizational Behavior and Human Decision Processes, 50(2), 248-287. doi:https://doi.org/10.1016/0749-5978(91)90022-L

Bandura, A., \& Jeffrey, R. W. (1973). Role of symbolic coding and rehearsal processes in observational learning. Journal of personality and social psychology, 26(1), 122-130. doi:10.1037/h0034205

Bari, F. (2000). Women in Pakistan: Asian Development Bank, Programs Department (West) and Office of Environment and Social Development.

BarNir, A., Watson, W. E., \& Hutchins, H. M. (2011). Mediation and moderated mediation in the relationship among role models, self-efficacy, entrepreneurial career intention, and gender. Journal of Applied Social Psychology, 41(2), 270-297. doi:doi:10.1111/j.1559-1816.2010.00713.x

Benight, C. C., \& Bandura, A. (2004). Social cognitive theory of posttraumatic recovery: The role of perceived self-efficacy. Behaviour Research and Therapy, 42(10), 1129-1148. doi:https://doi. org/10.1016/j.brat.2003.08.008

Bernard, H. R. (2002). Qualitative data analysis I: text analysis. Research methods of anthropology, 440-448. 
Bosma, N., Hessels, J., Schutjens, V., Praag, M. V., \& Verheul, I. (2012). Entrepreneurship and role models. Journal of Economic Psychology, 33(2), 410-424. doi:https://doi.org/10.1016/j.joep.2011.03.004

Boukamcha, F. (2015). Impact of training on entrepreneurial intention: An interactive cognitive perspective. European Business Review, 27(6), 593-616. doi:doi:10.1108/EBR-12-2014-0090

Braun, V., \& Clarke, V. (2006). Using thematic analysis in psychology. Qualitative Research in Psychology, 3(2), 77-101. doi:10.1191/1478088706qp063oa

Bullough, A., Renko, M., \& Abdelzaher, D. (2017). Women's business ownership: Operating within the context of institutional and in-group collectivism. Journal of Management, 43(7), 2037-2064. doi:10.1177/0149206314561302

Burrell, G., \& Morgan, G. (1979). Sociological paradigms and organisational analysis elements of the sociology of corporate life. London: Routledge.

Carson, D., Gilmore, A., Perry, C., \& Gronhaug, K. (2001). Qualitative marketing research: Sage. Cherry, K. (Producer). (2012). Social Learning Theory: An Overview of Bandura's Social Learning Theory.

Chlosta, S., Patzelt, H., Klein, S. B., \& Dormann, C. (2012). Parental role models and the decision to become self-employed: The moderating effect of personality. Small Business Economics, 38(1), 121 138. doi:10.1007/s11187-010-9270-y

Choi, J., Hecht, G., Tafkov, I. D., \& Towry, K. L. (2015). Vicarious learning under implicit contracts. The Accounting Review, 91(4), 1087-1108.

Cohen, D. J., \& Crabtree, B. F. (2008). Evaluative criteria for qualitative research in health care: controversies and recommendations. The Annals of Family Medicine, 6(4), 331-339.

Connolly, G. J. (2017). Applying social cognitive theory in coaching athletes: The power of positive role models. Strategies, 30(3), 23-29. doi:10.1080/08924562.2017.1297750

Cox, L., Mueller, S., \& Moss, S. (2002). The impact of entrepreneurship education on entrepreneurial self-efficacy. International Journal of Entrepreneurship Education, 1(2), 229-245.

Creswell, J. W., Klassen, A. C., Plano Clark, V. L., \& Smith, K. C. (2011). Best practices for mixed methods research in the health sciences. Bethesda (Maryland): National Institutes of Health, 2013, 541-545.

Davidsson, P. (2005). Methodological approaches to entrepreneurship: Past research and suggestions for the future. Small Enterprise Research, 13(1), 1-21. doi:10.5172/ser.13.1.1

Davis, A. (2011). Rural and urban women entrepreneurs $\$$ sa comparison of service needs and delivery methods priorities. International Journal of Business Science $\mathcal{E}$ Applied Management (IJBSAM), 6(2), 1-16.

DeSantis, L., \& Ugarriza, D. N. (2000). The concept of theme as used in qualitative nursing research. Western Journal of Nursing Research, 22(3), 351-372. doi:10.1177/019394590002200308

Ekanem, I. (2015). Entrepreneurial learning: Gender differences. International Journal of Entrepreneurial 
Behavior EF Research, 21(4), 557-577. doi:doi:10.1108/IJEBR-08-2014-0146

Entrialgo, M., \& Iglesias, V. (2017). Are the intentions to entrepreneurship of men and women shaped differently? The impact of entrepreneurial role-model exposure and entrepreneurship education. Entrepreneurship Research Journal, 8(1), 1-14. doi:10.1515/erj-2017-0013

Flick, U. (2009). The sage qualitative research kit: Collection: SAGE Publications Limited.

Gibb, A. (2002). In pursuit of a new 'enterprise' and 'entrepreneurship' paradigm for learning: creative destruction, new values, new ways of doing things and new combinations of knowledge. International Journal of Management Reviews, 4(3), 233-269. doi:doi:10.1111/1468-2370.00086

Gohar, M., Rauf, A., \& Abrar, A. (2011). Making of household entrepreneurs: Lived experiences of pukhtoon women entrepreneurs from Peshawar, Pakistan. Paper presented at the ICSB World Conference Proceedings.

Guiso, L., Pistaferri, L., \& Schivardi, F. (2015). Learning entrepreneurship from other entrepreneurs? (No. w21775). National Bureau of Economic Research.

Hanif, M. I., Meryem, M., Rao, H., \& Nawaz, M. K. (2017). Women’s entrepreneurship in rural areas of punjab, pakistan: How are women possess and supervising home-based businesses aggravated to grow. Review of Integrative Business and Economics Research, 6(3), 308.

Huber, J. (2013). Applying educational psychology in coaching athletes: Human Kinetics.

Hudson, L. A., \& Ozanne, J. L. (1988). Alternative ways of seeking knowledge in consumer research. Journal of Consumer Research, 14(4), 508-521. doi:10.1086/209132

Jamali, D. (2009). Constraints and opportunities facing women entrepreneurs in developing countries: A relational perspective. Gender in management: An international journal, 24(4), 232-251.

Kc, D., Staats, B. R., \& Gino, F. (2013). Learning from my success and from others' failure: Evidence from minimally invasive cardiac surgery. Management Science, 59(11), 2435-2449.

King, N. (2004). Using templates in the thematic analysis of text. In Cassell, C. \& Symon, G. (Eds.) Essential guide to qualitative methods in organizational research. (pp. 256-270). London: Sage Publications.

Kirk, J., Miller, M. L., \& Miller, M. L. (1986). Reliability and validity in qualitative research: Sage Publications.

Liñán, F., Urbano, D., \& Guerrero, M. (2011). Regional variations in entrepreneurial cognitions: Start-up intentions of university students in Spain. Entrepreneurship E Regional Development, 23(3-4), 187-215. doi: $10.1080 / 08985620903233929$

Manz, C. C., \& Sims Jr, H. P. (1981). Vicarious learning: The influence of modeling on organizational behavior. Academy of Management Review, 6(1), 105-113.

Maritz, A., \& Brown, C. (2013). Enhancing entrepreneurial self-efficacy through vocational entrepreneurship education programmes. Journal of Vocational Education $\mathcal{E}$ Training, 65(4), 543-559. doi:1 $0.1080 / 13636820.2013 .853685$ 
Markussen, S., \& Røed, K. (2017). The gender gap in entrepreneurship-The role of peer effects. Journal of Economic Behavior $\mathcal{E}$ Organization, 134, 356-373.

McCracken, G. (1988). The long interview. Newbury Park, CA: SAGE Publications.

Merriam, S. B., \& Tisdell, E. J. (2015). Qualitative research: A guide to design and implementation: John Wiley \& Sons.

Miller, N. E., \& Dollard, J. (1941). Social learning and imitation. New Haven, CT, US: Yale University Press.

Mohsin, Z. R. (2013). The crisis of internally displaced persons (IDPs) in the federally administered tribal areas of Pakistan and their impact on Pashtun women. Tigah: A Journal of Peace and Development, 3(2), 92-117.

Moustaghfir, K., \& Schiuma, G. (2013). Knowledge, learning, and innovation: research and perspectives. Journal of Knowledge Management, 17(4), 495-510. doi:doi:10.1108/JKM-04-2013-0141

Muhammad, A., Akbar, S., \& Dalziel, M. (2011). The journey to develop educated entrepreneurs: prospects and problems of Afghan businessmen. Education + Training, 53(5), 433-447. doi:doi: $10.1108 / 00400911111147730$

Myers, C. (2018). Coactive vicarious learning: Toward a relational theory of vicarious learning in organizations. Academy of Management review, 43(4), 1-55.

Newbery, R., Lean, J., Moizer, J., \& Haddoud, M. (2018). Entrepreneurial identity formation during the initial entrepreneurial experience: The influence of simulation feedback and existing identity. Journal of Business Research, 85, 51-59. doi:https://doi.org/10.1016/j.jbusres.2017.12.013

Nikolić, N., Jovanović, I., Nikolić, Đ., Mihajlović, I., \& Schulte, P. (2018). Investigation of the factors influencing sme failure as a function of its prevention and fast recovery after failure. Entrepreneurship Research Journal, 9(3), 1-21.

Ozgen, E., \& Baron, R. A. (2007). Social sources of information in opportunity recognition: Effects of mentors, industry networks, and professional forums. Journal of Business Venturing, 22(2), 174-192. doi:https://doi.org/10.1016/j.jbusvent.2005.12.001

Ponelis, S. R. (2015). Using interpretive qualitative case studies for exploratory research in doctoral studies: A case of Information Systems research in small and medium enterprises. International Journal of Doctoral Studies, 10(1), 535-550.

Rae, D. (2000). Understanding entrepreneurial learning: a question of how? International Journal of Entrepreneurial Behavior E Research, 6(3), 145-159. doi:doi:10.1108/13552550010346497

Rae, D., \& Wang, C. L. (2015). Entrepreneurial learning: Past research and future challenges. In Entrepreneurial Learning (pp. 25-58): Routledge.

Rehman, S., \& Azam Roomi, M. (2012). Gender and workllife balance: A phenomenological study of women entrepreneurs in Pakistan. Journal of Small Business and Enterprise Development, 19(2), 209. 


\section{8. doi:doi:10.1108/14626001211223865}

Roberts, M. A. (2010). Toward a theory of culturally relevant critical teacher care: African American teachers' definitions and perceptions of care for African American students. Journal of Moral Education, 39(4), 449-467. doi:10.1080/03057241003754922

Saeed, S., Muffatto, M., \& Yousafzai, S. (2014). A multi-level study of entrepreneurship education among Pakistani University Students. Entrepreneurship Research Journal, 4(3), 297-321.

Schunk, D. H. (2012). Learning theories an educational perspective (6 $6^{\text {th }}$ ed.). Pearson.

Sherazi, S. N., \& Zahra, N. (2015). Role of self-efficacy in shaping entrepreneurial intensions among women entrepreneurs venturing in Lahore, Pakistan. PUTAJ-Humanities and Social Sciences, 22(2), 99-109.

Spradley, J. (1979). The ethnographic interview. New York, NY: Holt, Rinehart and Winston.

St-Jean, É., \& Mathieu, C. (2015). Developing attitudes toward an entrepreneurial career through mentoring:the mediating role of entrepreneurial self-efficacy. Journal of Career Development, 42(4), 325-338. doi: $10.1177 / 0894845314568190$

Tariq, J. (2016). Exploring entrepreneurial motivations and barriers: A study of female business owners in Pakistan. University of Hull.

Thomas, P., \& Moisey, S. (2006). Women entrepreneurs: Informal learning and the Internet. Journal of Small Business $\mathcal{E}$ Entrepreneurship, 19(2), 183-202.

Vuorio, A. M., Puumalainen, K., \& Fellnhofer, K. (2018). Drivers of entrepreneurial intentions in sustainable entrepreneurship. International Journal of Entrepreneurial Behavior $\mathcal{E}$ Research, 24(2), 359-381. doi:doi:10.1108/IJEBR-03-2016-0097

Wager, K., \& Cox, S. (2009). Auricular acupuncture and addiction: Mechanisms, methodology and practice (1 $1^{\text {st }}$ ed.): Churchill Livingstone.

Wells, S. J. (2014). Women entrepreneurs: Developing leadership for success: Routledge.

Yadav, V., \& Unni, J. (2016). Women entrepreneurship: Research review and future directions. Journal of Global Entrepreneurship Research, 6(1), 12. doi:10.1186/s40497-016-0055-x

Yitshaki, R., \& Kropp, F. (2016). Motivations and opportunity recognition of social entrepreneurs. Journal of Small Business Management, 54(2) 546-565.

Zapkau, F. B., Schwens, C., Steinmetz, H., \& Kabst, R. (2015). Disentangling the effect of prior entrepreneurial exposure on entrepreneurial intention. Journal of Business Research, 68(3), 639-653. doi:https://doi.org/10.1016/j.jbusres.2014.08.007

Zozimo, R., Jack, S., \& Hamilton, E. (2017). Entrepreneurial learning from observing role models. Entrepreneurship Eु Regional Development, 29(9-10), 889-911. doi:10.1080/08985626.2017.1376518 
